\title{
落石防護補強土擁壁の数值解析と モデル実験による性能評価
}

\author{
吉田眞輝 1 熊谷幸博 2 橋本早苗 $3 \cdot$ 六佐公輔 4 ・荒井克彦 5
}

\begin{abstract}
落石防護補強土擁壁（以後, 補強土壁）は，13年ほど前に開発され数百〜数千 $\mathrm{kJ}$ と大規模エネルギーを持つ 落石に対して広く使用されてきた，その設計手法は落石衝突時のエネルギーを衝撃力に置き換えて極限つり合 い法による非変形（非破壊）の照査を行う手法が主であったが，近年では実証実験により得られたデータを元 に変形を考慮してさらに大きな落石に対しても許容する手法が提唱されている1 ${ }^{1}$. 本研究では補強土壁設計の 合理化を図るため, 実物実験結果の変形状態を3次元動的解析により再現し, 従来行われていた設計手法によ り決定される補強土壁形状との整合性を確認した。 さらに1/25スケールのモデル実験を行い, 解析で再現した 補強土壁の変形特性がモデル実験の挙動とほぼ同一であることが確認できた。 これらから落石規模や設置条件 による適用範囲を拡大できる指標ができたことを報告する.
\end{abstract}

キーワード : 落石, 3次元動的解析, 補強土擁壁, モデル実験

\section{1. はじめに}

補強土壁は土とジオグリッドにより構成された強度と 柔軟性を備えた構造物であるため, 衝突時の変状により 高い落石エネルギーを吸収できることは今までの実験や 被災事例報告 ${ }^{2}$ により確認されている. ただし落石エネ ルギーに対する許容変状量や，その変状量を維持する適 正な形状が明確ではないため, 変形を考慮する設計は実 物実験により得られた成果を元に決定していることが多 い. 実証実験タイプは実際の現象の確認であり信頼性は 高いが，補強土壁の形状が実証実験と異なる場合，性能 根拠に乏しくなる．そのため落石エネルギーが実証実験 で確認したものより小さくても実験形状で対応すること となり，時には不経済な形状になる場合がある。

それに対し従来の極限つり合い法による手法は，過去 の各種実験 ${ }^{3415)}$ により確立された設計手法で形状を決定 するため, 落石規模ごとの形状選定ができる. ただしこ の設計法は境界面での落石衝撃力と補強土壁の抵抗力の つり合いで照査するため, 変状を考慮していない. よっ て本設計により決定した形状は繰り返しの落石に抵抗で きる半面，変形を考慮できないため余耐力が大きい構造 であるともいえる.

落石発生斜面は急峻で狭い地形が多いため, 極力小さ な断面形状にすることが望まれ，変形は許容するがその 分小さくできるなど設計的な柔軟性が必要となっている. 本研究では解析とモデル実験の両側面から, 設計に反映
できるエネルギー規模に対する変形特性を確認する.

\section{2. 従来設計型の概要}

（1）従来型の形状と目安となる機能

従来設計における形状と目安としている落石エネルギ 一を図-1および表-1に示す.

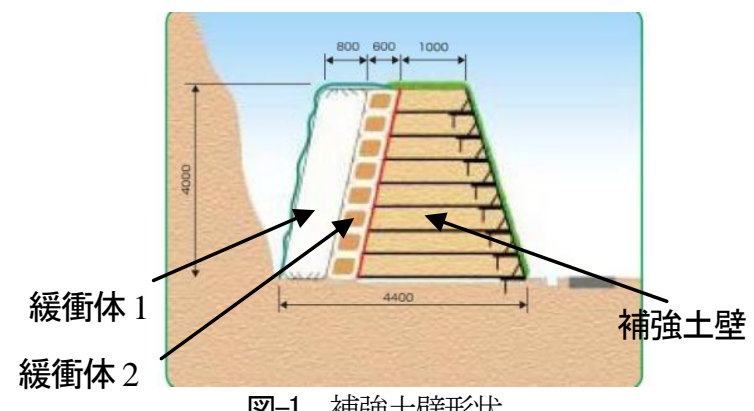

図-1＼cjkstart補強土壁形状

表-1 タイプ別適用目安

\begin{tabular}{|c|c|c|}
\hline タイプ & 目安のエネルギー $(\mathrm{kJ})$ & 必要設置幅 $(\mathrm{m})$ \\
\hline I 型 & 500 & $2.5 \sim 3.0$ \\
\hline II 型 & 1500 & $3.5 \sim 4.0$ \\
\hline III型 & 5500 & $4.5 \sim 5.5$ \\
\hline
\end{tabular}

補強土壁を本体として，落石規模によりジオテキスタ イル製の袋材に単粒度砕石などを投入した緩衝体を設置

1正会員，前田工繊株式会社＼cjkstart地盤防災推進部 斜面防災グループリーダー（广919-0422福井県坂井市春江町沖布目38-3）

2正会員，前田工繊株式会社＼cjkstart地盤防㷋推進部 部長（干919-0422福井県坂井市春江町沖布目38-3）

3,4非会員，前田工繊株式会社＼cjkstart地盤防災推進部（广919-0422福井県坂井市春江町沖布目38-3）

5国際会員, 福井大学 名誉教授（广910-8507福井県福井市文京3丁目9番1号) 
することでさらに高い落石エネルギーに対応できる構造 となり I 〜IIIまでの 3 タイプとなる. 各タイプの構成を 示す.

I 型 : 補強土壁のみ

II 型 : 補強土壁十緩衝体1

III型 : 補強土壁十緩衝体 1,2

擁壁形状であるため表-1に示すように比較的広い設置幅 を必要とすることも特徴である.

\section{（2）設計法}

先にも述べたように，本設計法では衝突部に作用する 落石衝撃力 $(\mathrm{P})$ に対し, 補強土壁の抵抗力 $\left(\mathrm{P}_{\mathrm{A}}\right)$ が大きい場 合に安定となる手法である. 本手法では緩衝体のない I II型では壁高相当の擁壁延長が影響範囲とされている. その設計モデルを図-2に示す. 落石の衝撃力は落石エ ネルギー算出要素となる落石重量および落下高さに特定 の定数を加味した「衝撃便覧の推式」により算出され た值を用いる. 推定式を式(1)に抵抗力の算出式を式(2) 示す.
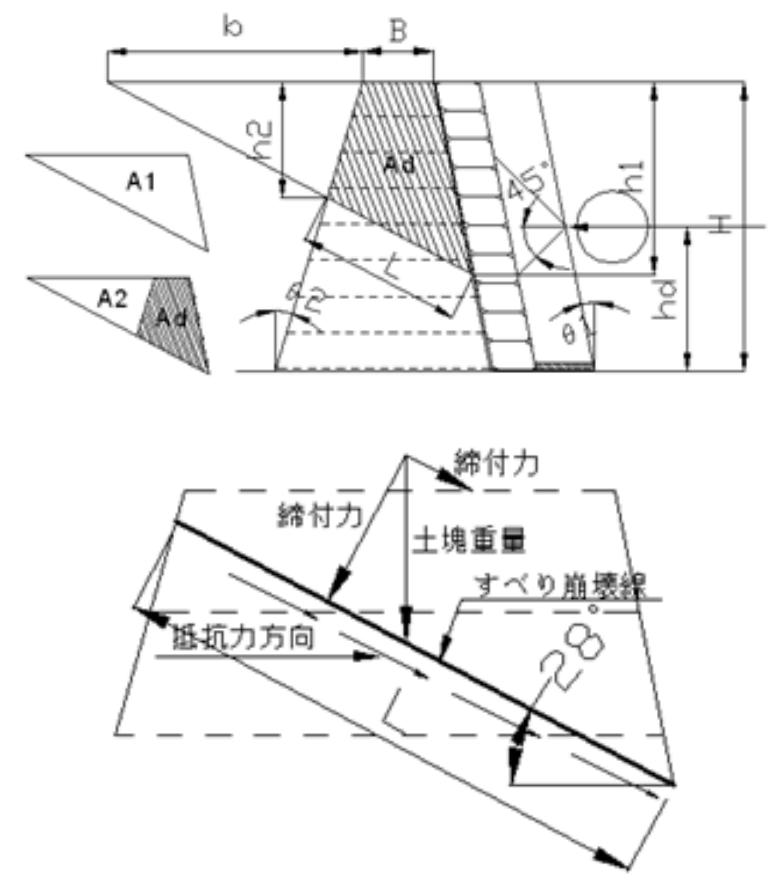

図-2 極限つり合い法による設計モデル

$$
\begin{aligned}
& \mathrm{P}= 2.108 \times \mathrm{mg}^{2 / a} \times \lambda^{2 / 5} \times \mathrm{H}^{\mathrm{a} / 5} \\
& \mathrm{P}_{\mathrm{A}}=\left(\mathrm{W}_{1} \cdot \sin \phi_{1}+\mathrm{W}_{1} \cdot \cos \phi_{1} \cdot \tan \phi+\mathrm{C}+\mathrm{L}\right) \times 1 \\
& \mathrm{P}: \text { 落石衝撃力 }(\mathrm{kN}) \\
& \mathrm{g}: \text { 落石質量 }(\mathrm{t}) \\
& \mathrm{m}: \text { 重力加速度 }\left(9.8 \mathrm{~m} / \mathrm{s}^{2}\right) \\
& \lambda: \text { 被衝突体のラーメの定数 }\left(530 \mathrm{kN} / \mathrm{m}^{3}\right) \\
& \mathrm{H}: \text { 落下高さ }(\mathrm{m}) \\
& \mathrm{P}_{\mathrm{A}}: \text { 補強土壁のすべり抵抗力 }(\mathrm{kN} / \mathrm{m}) \\
& \mathrm{W}_{1}: \text { 抵抗士塊重量 }(\mathrm{kN}) \\
& \mathrm{C}: \text { 補強効果による見かけの粘着力 }\left(\mathrm{kN} / \mathrm{m}^{2}\right)
\end{aligned}
$$
$\mathrm{L}:$ すべり線の距離 $(\mathrm{m})$
$1:$ 影響範囲 $(\mathrm{m}:$ 壁高 $4.0 \mathrm{~m} の$ 場合は4.0m)

緩衝体1，2は特定の性能を持ったものとして設計に反 映されている．各緩衝体により緩和された衝撃力に対し て補強土壁部が抵抗する。緩衝体がない場合は補強土壁 部の抵抗力のみとなる. よって以後の検証では，落石エ ネルギーに対する補強土壁部の変形特性の照査を行う。

\section{3 次元動的解析}

\section{（1）落石防護効果の検証方法}

落石対策は，落石を捕捉する動的な現象であるため, 動的解析によく使用されるLS-DYNA(V971R6.10)を用い て3次元動的解析を行った. 本解析は有限要素法の中で も追突，落下解析など非常に短い時間で起こる衝撃的な 現象を解析するのに用いられる陽解法により構造物の大 変形挙動を時刻歴で解析できるもので，落石による補強 土壁の挙動を解析するのに適していると判断し採用した。 解析モデルは過去に実施された実物実証実験の結果 ${ }^{1}$ か ら採用した. モデル形状は実物大実験時の形状で壁高さ $4.2 \mathrm{~m}$ ，補強土壁天端幅 $1.4 \mathrm{~m}$ ，落石衝突面勾配1：0.2，裏 面勾配1：0.3を基本形とした。補強土壁延長は $14.0 \mathrm{~m}$ と て擁壁延長の影響を考慮した。これに実証実験で計測さ れた線速度を与えた時の推定落石エネルギー2,270kJ時の 変形量の解析結果を，実証実験で計測された変形量と比 較して，本解析が実際の現象を再現できることを検証し た（表-2のケース1が実証実験に対応する）。次に，表2に示すケース2〜4で解析を実施し, 補強土壁の高さ・ 形状の影響を検討した. ケース2〜4の解析時のエネルギ 一は，ケース 1 の形状で補強土壁の許容変形量（背面変 状 $150 \mathrm{~mm} ）$ 以内となる限界エネルギーとして設定されて いる数值を採用した. 形状諸元の概略図を図-3に示す. 解析時の各物性を表-3に示す.

表-2 解析ケース

\begin{tabular}{|c|c|c|c|c|}
\hline ケース & 高さ $(\mathrm{m})$ & 天端幅 $(\mathrm{m})$ & 落石 $\mathrm{E}(\mathrm{kJ})$ & 衝突高さ $(\mathrm{m})$ \\
\hline ケース & 4.2 & 1.40 & 2,270 & 2.146 \\
\hline ケース2 & 4.2 & 1.40 & 1,400 & 2.146 \\
\hline ケース3 & 3.0 & 1.40 & 1,400 & 2.0 \\
\hline ケース4 & 3.0 & 2.68 & 1,400 & 2.0 \\
\hline
\end{tabular}

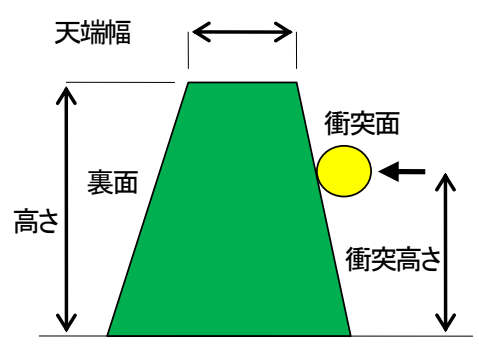

図-3 解析ケース概略図 
表-3 解析時の各物性

- 基礎地盤（弾性体）

\begin{tabular}{|c|c|}
\hline 単位体積重量 $\left(\mathrm{t} / \mathrm{m}^{3}\right)$ & 2.0 \\
\hline ポアソン比 $(\mu)$ & 0.33 \\
\hline 変形係数 $\left(\mathrm{N} / \mathrm{m}^{2}\right)$ & $5.6 \times 10^{7}$ \\
\hline $\mathrm{N}$ 值 & 20 \\
\hline
\end{tabular}

・盛土材 (モールクーロン)

\begin{tabular}{|c|c|}
\hline 単位体積重量 $\left(\mathrm{t} / \mathrm{m}^{3}\right)$ & 1.8 \\
\hline ポアソン比 $(\mu)$ & 0.33 \\
\hline 変形係数 $\left(\mathrm{N} / \mathrm{m}^{2}\right)$ & $2.8 \times 10^{7}$ \\
\hline $\mathrm{N}$ 值 & 10 \\
\hline 内部摩擦係数 $\left(^{\circ}\right)$ & 25 \\
\hline 粘着力 $\left(\mathrm{kN} / \mathrm{m}^{2}\right)$ & 35 \\
\hline
\end{tabular}

※変形係数は $2800 \mathrm{~N}$ から算出

・補強材および壁面材

\begin{tabular}{|l|c|}
\hline ジオグリッド1 & $\mathrm{T}=36.0 \mathrm{kN} / \mathrm{m}$ 伸度 $10 \%$ 材質HDPE 1軸方向強度 \\
\hline ジオグリッド2 & $\mathrm{T}=10.0 \mathrm{kN} / \mathrm{m}$ 伸度 $10 \%$ 材質PP 3軸方向強度 \\
\hline 壁面材 & 溶接金網 $\mathrm{E}=2.0 \times 105 \mathrm{~N} / \mathrm{mm}^{2} \mathrm{v}=7.85 \mathrm{t} / \mathrm{m}^{3}$ \\
\hline
\end{tabular}

・重鏵（ケース1）

\begin{tabular}{|c|c|}
\hline 直径 $(\mathrm{m})$ & 2.108 \\
\hline 質量 $(\mathrm{t})$ & 17.1 \\
\hline 進入速度 $(\mathrm{m} / \mathrm{s})$ & 16.3 \\
\hline 弾性係数 $\left(\mathrm{kN} / \mathrm{m}^{2}\right)$ & $2.35 \times 10^{7}$ \\
\hline
\end{tabular}

・重錘（ケース2〜3)

\begin{tabular}{|c|c|}
\hline 直径 $(\mathrm{m})$ & 1.0 \\
\hline 質量 $(\mathrm{t})$ & 1.36 \\
\hline 進入速度 $(\mathrm{m} / \mathrm{s})$ & 45.35 \\
\hline 弾性係数 $\left(\mathrm{kN} / \mathrm{m}^{2}\right)$ & $2.35 \times 10^{7}$ \\
\hline
\end{tabular}

基礎地盤・盛土材・補強材および壁面材は同一の物性と して解析を行った。重鏵は物性は同一であるが，ケース 1は実物実験の再現であるため，実際使用された重錘質 量と実測の進入速度を採用した。 ケース2〜3については 任意の落石エネルギーに合わせるため，重錘形状を直径 $1.0 \mathrm{~m}$ で固定し，進入速度を $1400 \mathrm{~kJ}$ となるように逆算した 数值を採用した. その際重錘の単位重量は一般的に落石 検討に用いられる $\gamma=2.6 \mathrm{t} / \mathrm{m}^{3}$ から重錘質量を算出した. 落石エネルギーの算出式を式(3), 落石重量の算出式を 式(4)にそれぞれ示す.

$$
\mathrm{E}=1 / 2 \mathrm{~m} \cdot \mathrm{V}^{2}
$$

$$
\begin{aligned}
& \mathrm{W}=\gamma \cdot \pi \cdot \mathrm{D}^{3} / 6 \quad(4) \\
& \mathrm{E}: \text { 落石エネルギ一 }(\mathrm{kJ}) \\
& \mathrm{m}: \text { 落石質量 }(\mathrm{t}) \\
& \mathrm{V}: \text { 落石の進入速度 }(\mathrm{m} / \mathrm{s}) \\
& \gamma: \text { 落石の単位体積重量 }(\mathrm{t}) \\
& \mathrm{D}: \text { 落石の直径 }(\mathrm{m})
\end{aligned}
$$

\section{（2）動的解析の結果}

変位測点は補強土壁背面天端から鉛直方向に $600 \mathrm{~mm}$ ピッチで測点を設けた。 これは壁面材一段分の高さであ り，ジオグリッド 1 の敷設間隔でもある．ケース 1〜2 は壁高さが高いため天端から 6 点，ケース 3〜4 は壁高 さが低いため天端から 4 点の測点を設けた．各ケースで の最大変位量と，最大変位が確認できた位置を表-4に 示す. 各ケースの変状および各測点での時系列変位を表 した解析図などを図-6９ にそれぞれ示す。変形量は落 石衝突時裏面に発生した水平方向の変位を示す.

表-4 各ケースの最大変位と発生位置

\begin{tabular}{|c|c|c|}
\hline ケース & 最大変位量 $(\mathrm{mm})$ & $\begin{array}{c}\text { 最大変位の確認できた位置 } \\
\text { (天端からの位置: } \mathrm{mm} \text { ) }\end{array}$ \\
\hline ケース 1 & 415 & 天端-1200 \\
\hline ケース2 & 135 & 天端-1200 \\
\hline ケース3 & 260 & 天端-0 \\
\hline ケース4 & 95 & 天端-600 \\
\hline
\end{tabular}

図-4〜5 に本解析の 3 次元解析図を示寸. 図はケース 1 の挙動を示すもので，重錘が貫入するに従い背面方向に も広く衝撃力が伝達してゆくのが確認できた. 影響範囲 は擁壁延長のほぼ半分であり，全延長が $14.0 \mathrm{~m}$ であるた め約 $7.0 \mathrm{~m}$ と考えられる. 2 章(2)の従来設計法の解説で 緩衝体 2 がないケースでは壁高相当の影響範囲と述べた が，その 2 倍近い影響範囲が確認される.これは従来設 計法の目安のエネルギーを大きく超えると変形が卓越す るとともに影響範囲が広がってゆくと考えられる.

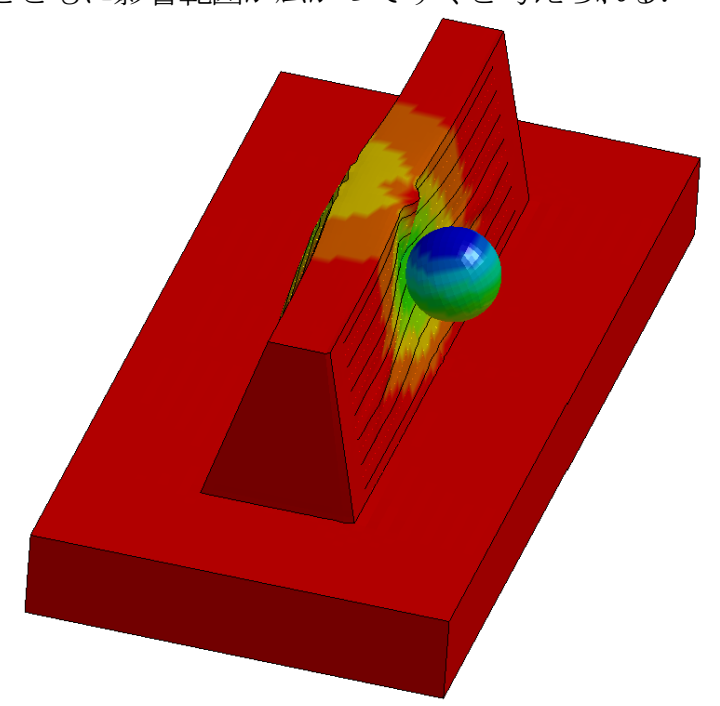

図-4 3 次元解析図（受撃部斜め前方）

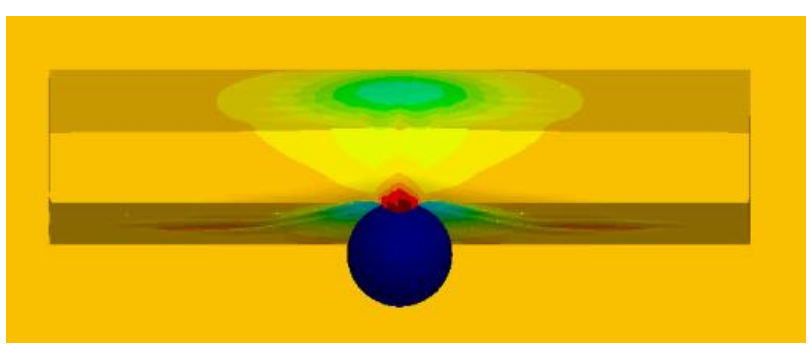

図-5 3 次元解析図 (上方) 

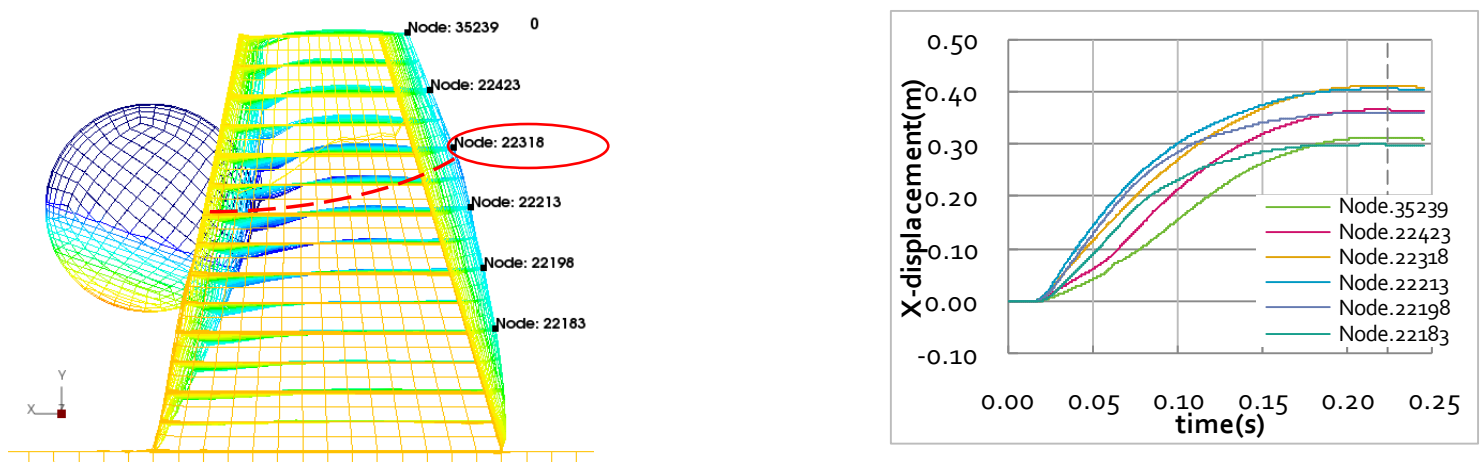

図-6 ケース 1変状図及び各測点における時系列変位
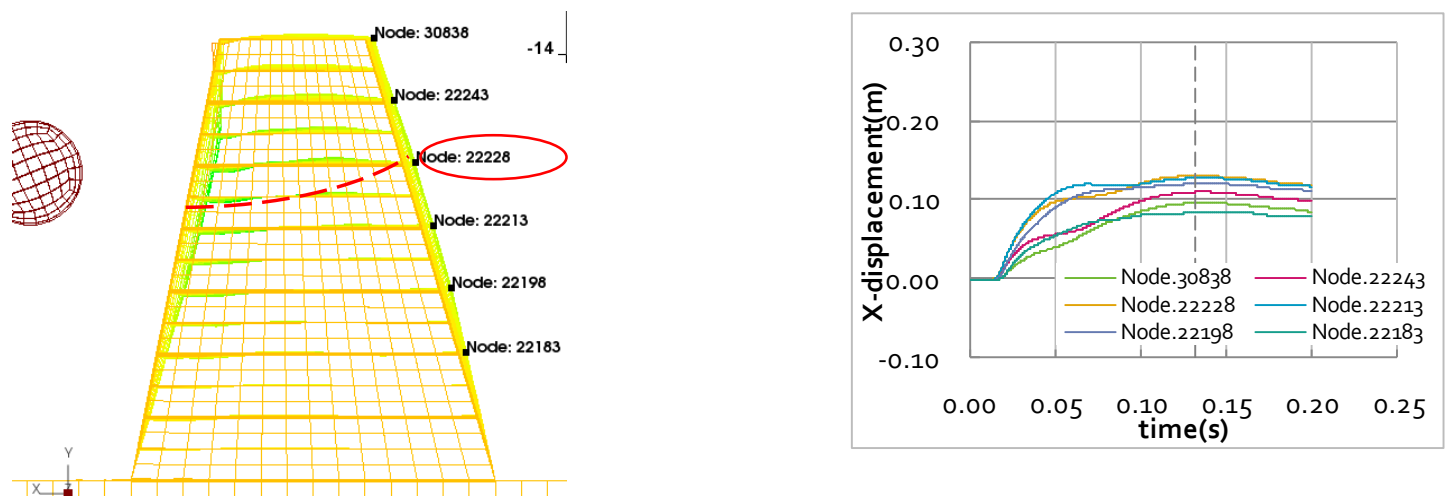

図-7 ケース 2変状図及び各測点における時系列変位
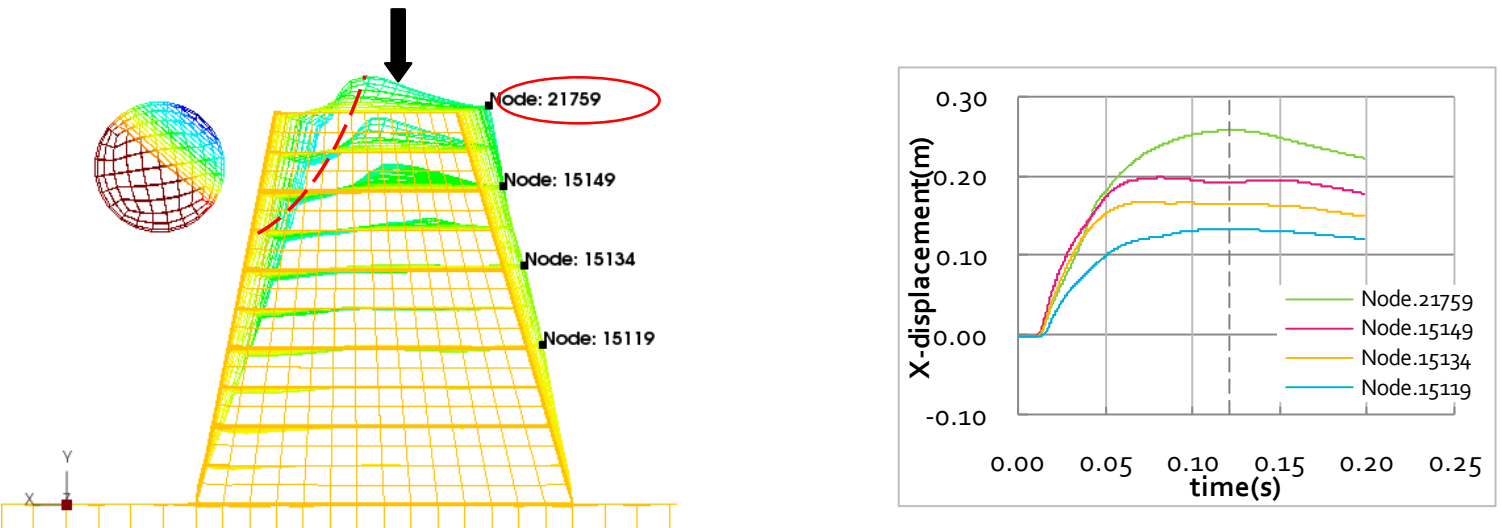

図-8 ケース 3変状図及び各測点における時系列変位
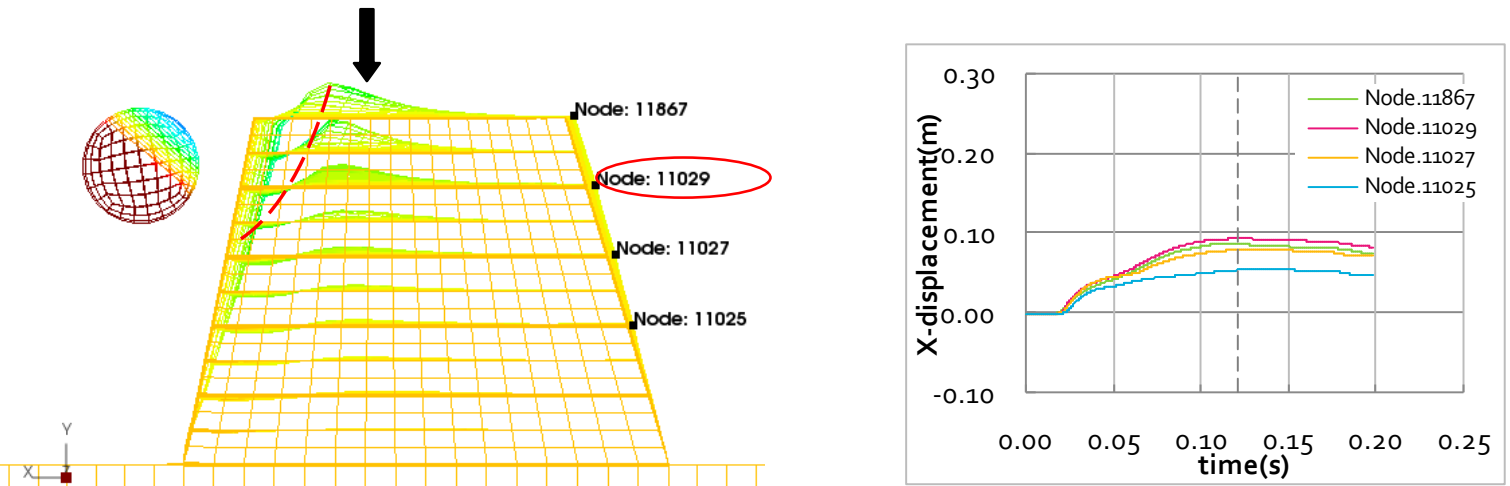

図-9 ケース4変状図及び各測点における時系列変位

形状が同じでエネルギーレベルを変えたケース 1 と 2 を比較するとそれぞれの最大変位が $415 \mathrm{~mm}, 135 \mathrm{~mm}$ とな っている. 落石エネルギ一が 1.6 倍程あるため変位量が 大きくなっているが，最大変位が確認できる位置は補 強土壁天端－1200mm とほぼ同一の位置で発生しており これは落石衝突位置よりやや上方であるが，ほぼ背面と なる位置である，次にエネルギーが同じで壁高さの異な るケース 2 と 3 を比較すると最大変位量はケース 3 で 
$260 \mathrm{~mm}$ とケース 2 のほぼ 2 倍になっている. 最大変位の 発生位置はケース 3 では裏面天端付近となっている。 ま た変状図では背面の最大変位個所以上の変状が天部に発 生していることが確認できる，壁高さおよびエネルギー が同一で断面幅の異なるケース 3 と 4 を比較すると, 最 大変位はケース 4 で $95 \mathrm{~mm}$ と比較的小さな変位量となっ ているがケース 3 同様，天部に大きな変状があることが 解析図より確認できる. 最大変位は天端－600 mm とケ 一ス 1，2 と比べやや高い位置で確認される.

解析図における落石衝突位置と最も変状が大きな個所 を結んだものを図中に点線で示す．これを落石衝撃力に よるすべり線と考えると, 従来手法の極限つり合い法に おける境界面のような線ができる. 特に壁高さの高いも のでは，この位置が設計モデルと近似することが確認で きる.

これにより，落石エネルギーに対し壁高さが低い（適 正でない）と抵抗土塊の抑止力が小さくなり，裏面や天 部など全体的に大きな変状が発生すると考えられる. ま たケース 4 のように断面幅が広い場合でも，背面への変 状は発生しにくくなるが，抵抗力の小さい衝突部近辺の 天端部で影響が出やすい結果となった.

\section{（3）従来設計法との比較}

極限平衡法による設計では，補強土のみの I 型では $500 \mathrm{~kJ}$ 程度の落石エネルギーを目安の許容エネルギーと している.よってここでは従来設計法で500kJに相当す る落石衝撃力に対応できる形状となる天端幅 $1.5 \mathrm{~m}$, 壁高 $3.5 \mathrm{~m}$ の補強土壁で解析を行った. また従来手法では通常

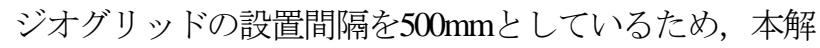
析のモデルでは同様としている. 衝突面および背面の勾 配は先の解析と同様である。図-10に解析図と各測点の 時系列変位を示す. 結果最大変位量は75mm と先の解析 結果のいずれよりも小さく, 衝突位置と背面変状位置を 結んだすべり線は天端 - $1000 \mathrm{~mm}$ ほどの位置となってお り, 従来設計法で設定する境界線と近似した位置となっ た.

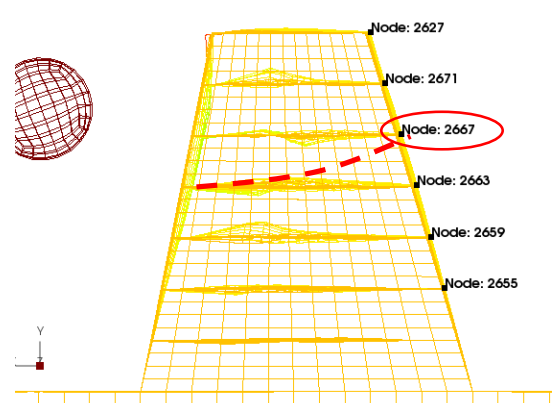

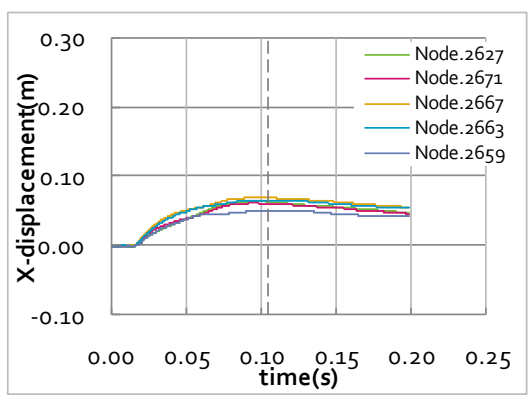

図-10 従来設計法との比較における結果

\section{4. モデル実験}

\section{（1）モデル実験の概要}

\section{a) 試験装置}

これまでの解析から従来設計法と, 変形を許容した設 計法はほぼ一致することを確認できた. ここでは解析で 確認した挙動が，実際の落石時の挙動と一致するかをモ デル実験により確認した。モデル実験は実物形状の $1 / 25$ で試験体を構築し，落石に見立てた鉄球をガイドレール 上を転落させたのち試験体に衝突させ，その挙動を確認 した. 写真-1に試験装置の全景を示す.

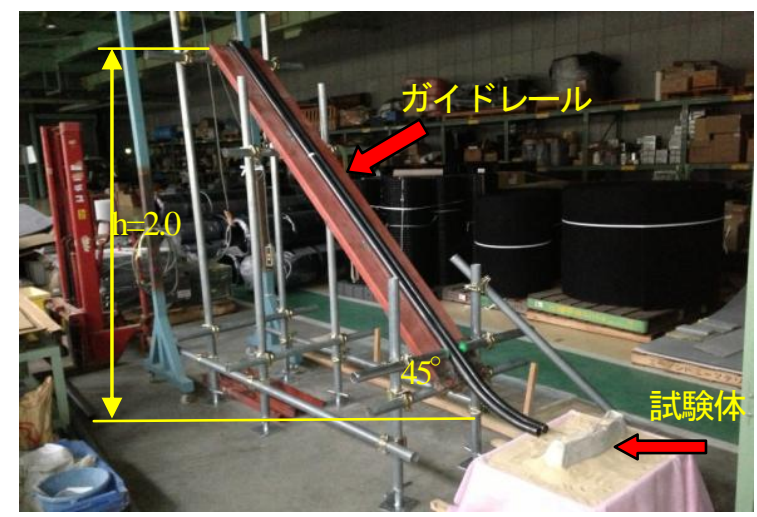

写真-1 試験装置全景

\section{b) 試験条件}

試験体の形状は解析モデルとほぼ同様であるが，3章 の解析で従来設計法との整合性が得れたため, 従来設計 法で標準的に採用されている部材および部材の設置手法 で行った.ここではジオグリッドは延長方向に連続に敷 設した．モデル形状を表-5，部材特性を表-6に示す.

表-5 モデルケース一覧表

\begin{tabular}{|c|c|c|c|}
\hline \multirow{2}{*}{ ケース } & 規 格 & 壁高さ $(\mathrm{mm})$ & 天端幅 $(\mathrm{mm})$ \\
\hline \multirow{2}{*}{ ケース1 } & 実物スケール & 4,000 & 1,000 \\
\cline { 2 - 4 } & モデル形状 & 160 & 40 \\
\hline \multirow{2}{*}{ ケース2 } & 実物スケール & 3,000 & 1,000 \\
\cline { 2 - 4 } & モデル形状 & 120 & 40 \\
\hline \multirow{2}{*}{ ケース3 } & 実物スケール & 3,000 & 2,680 \\
\cline { 2 - 4 } & モデル形状 & 120 & 110 \\
\hline
\end{tabular}


表-6 部材物性

\begin{tabular}{|c|c|c|}
\hline 部材 & & 物性 \\
\hline \multirow{2}{*}{ ジオグリッド } & 実物 & $50 \mathrm{kN} / \mathrm{m} \times 50 \mathrm{kN} / \mathrm{m}$ 二軸ジオグリッド \\
\hline & モデル用 & コンウェッドネットR07107(314N/3インチ) \\
\hline \multirow{2}{*}{ 壁面材 } & 実物 & 断面係数 $0.838 \mathrm{~mm} 3 / \mathrm{mIキスパンドメタル}$ \\
\hline & モデル用 & 断面係数 $0.071 \mathrm{~mm} 3 / \mathrm{m}$ 相当メツシュ金網 \\
\hline $\begin{array}{l}\text { 盛土材 } \\
\end{array}$ & & 砂質土( $\mathrm{y} 19 \mathrm{kN} / \mathrm{m}^{3}, \varphi 30^{\circ}$ 程度) \\
\hline
\end{tabular}

\section{c）作用エネルギー}

本試験では直径1.0m程度の落石が衝突することを想定 し， $\phi 40 \mathrm{~mm}$ 鉄球を使用した。鉄球の進入速度は，高 低差 $2.0 \mathrm{~m}$ 試験装置から鉄球を落下させ飛び出す瞬間を 1/60秒のスローモーションカメラで撮影しその移動距離 から速度を推定した。 その結果約 $\mathrm{V}=6.0 \mathrm{~m} / \mathrm{s}$ と確認された。 これを試験時の進入速度として実物スケールの落石エネ ルギーを推定するとおよそ1,800kJ程度と考えられる。

\section{(2) 計測項目}

鉄球衝突後裏面に発生する変位を計測した。鉄球の衝 突位置は落石の設計でよく用いられる跳躍量 $2.0 \mathrm{~m} の 1 / 25$ として底部より $80 \mathrm{~mm}$ の位置に衝突させた，図-11，12に 示す計測高さごとに設置した水系からの離隔を衝突前後 に計測し，その差異を残留変位とした，最大変位は裏面 中央付近に設置したロッド式変位計により動的測定を行 った. 写真-2に計測設備を示す.

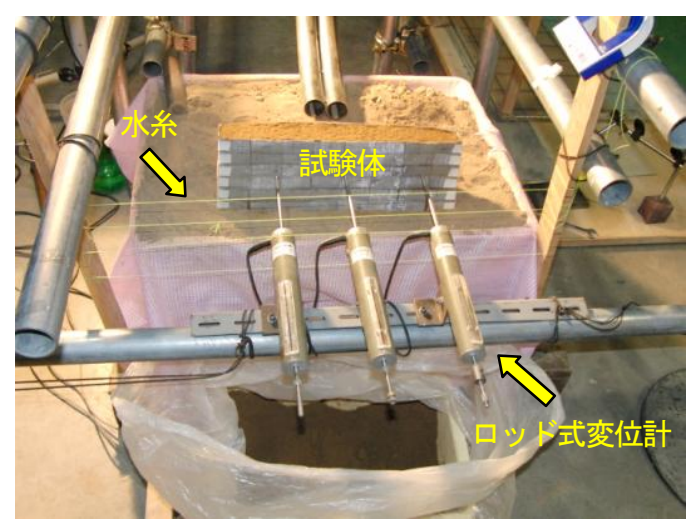

写真-2 計測設備

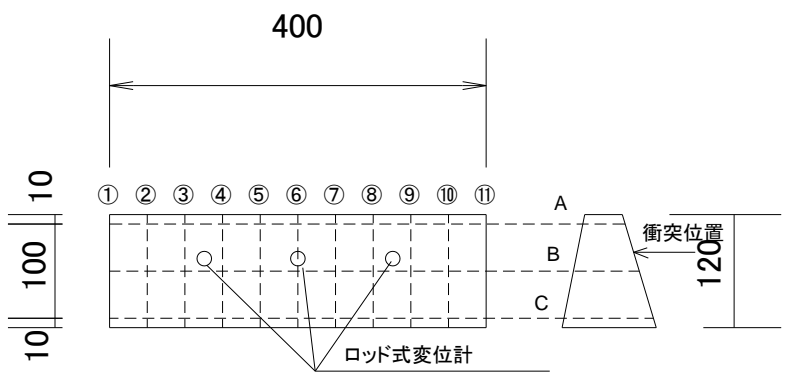

図-11 背面変位計測個所 $(\mathrm{H}=3.0 \mathrm{~m}$ ケース 2,3$)$

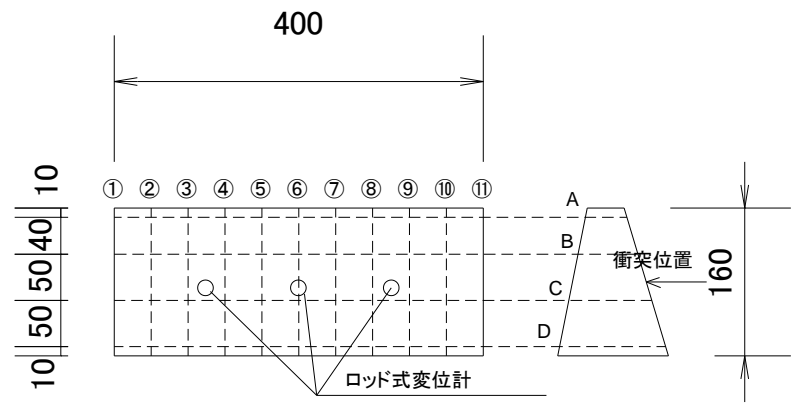

図-12 背面変位計測個所 $(\mathrm{H}=4.0 \mathrm{~m}$ ケース 1$)$

\section{(3) 試験結果}

\section{a)残留変位}

図-13〜15にケースごとの残留変位を示す．ケース1, 3 では残留変位が $1.0 \mathrm{~mm}$ 程度である。ケース 2 では $5.0 \mathrm{~mm}$ 程度であり，これを実物大に換算し25倍するとケース 1 , 3では $25 \mathrm{~mm}$ 程度，ケース 2 では $125 \mathrm{~mm}$ 程度と考えられる。 ケース1，3は変位が小さいため判別しにくいが，ケース 2では3次元動的解析同様天端に近い位置で最大の残留変 位が確認できる。 またケース3においては裏面変状は小 さいものの, 解析同様衝突面の天端付近に変状が発生し ていることが確認できた.

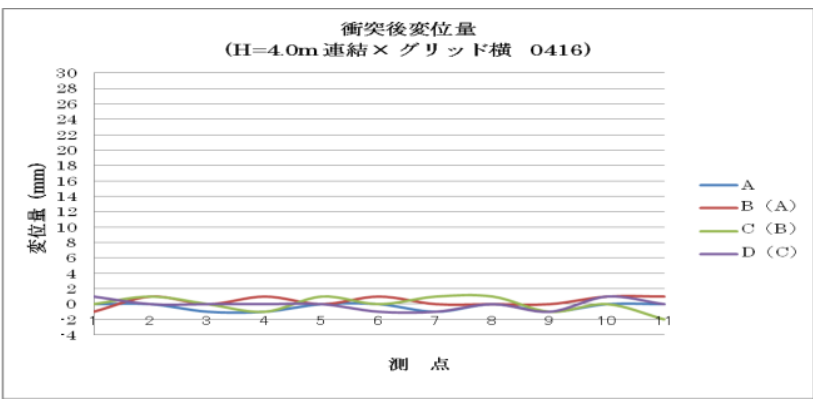

図-13 ケース2衝突後残留変位

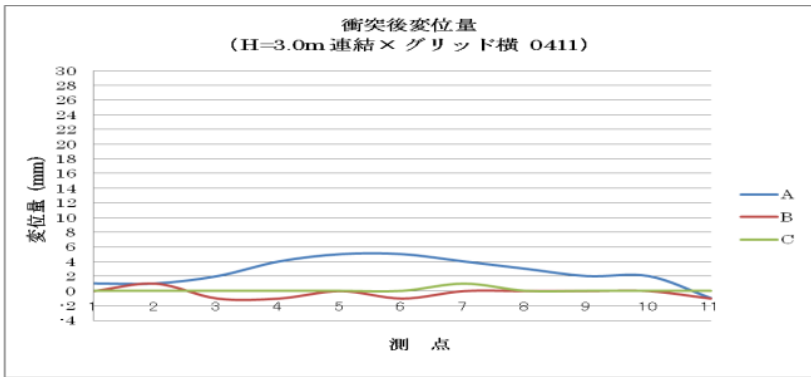

図-14 ケース2衝突後残留変位

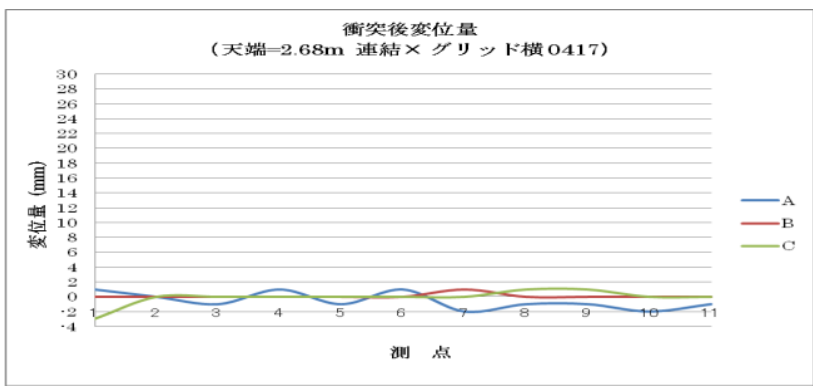

図-15 ケース2衝突後残留変位 


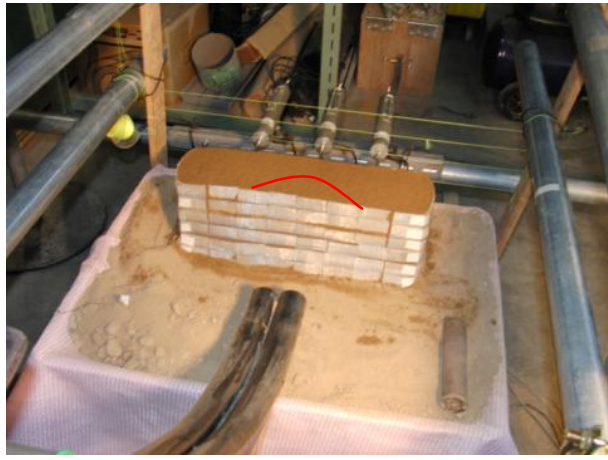

写真-3 ケース3の天端部変状

\section{b) 最大変位}

ロッド式変位計で確認した最大変位を図-16〜18に示 す. ケース 1 3でそれぞれ $8.2 \mathrm{~mm}, 17.5 \mathrm{~mm}, 4.2 \mathrm{~mm}$ の最 大変位が確認されそれぞれ実物大に換算寸ると $205 \mathrm{~mm}$, 437.5mm，105mmとなり解析結果より若干大きな值とな ったが解析と同様の傾向であるとともにいずれのケース でも破壊には至らなかった。 また衝突後中央部のピーク から少し遅れて両端のピークが発生した後振幅するよう な挙動が確認できる。これは補強土壁が弾性領域内であ ると思われ，その影響はジオグリッドを延長方向に敷設 し，一体性が向上していることに起因していると思われ る.

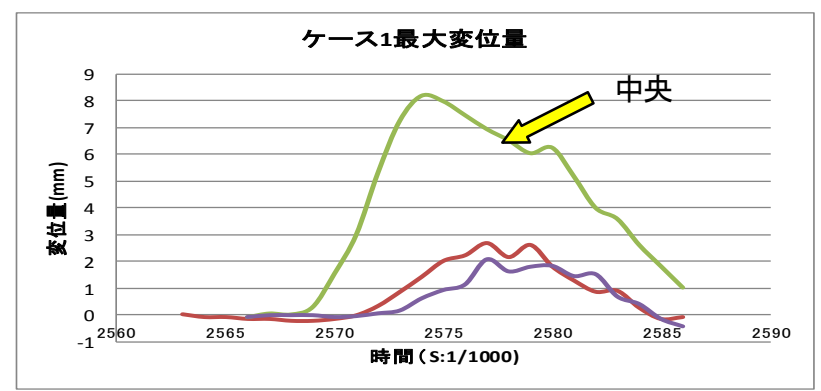

図-16 ケース1最大変位量

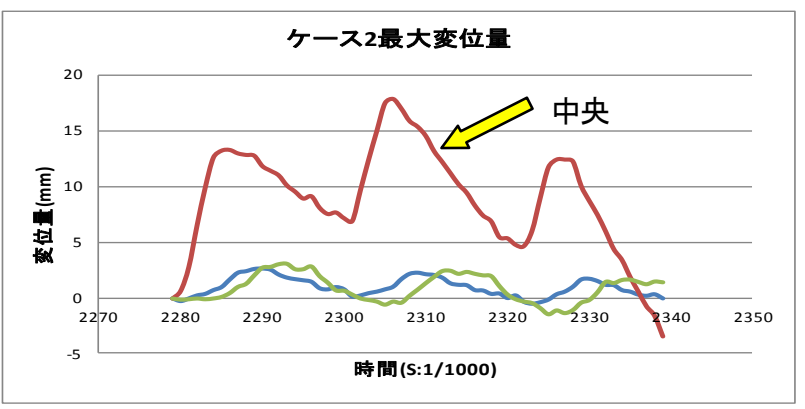

図-17 ケース2最大変位量

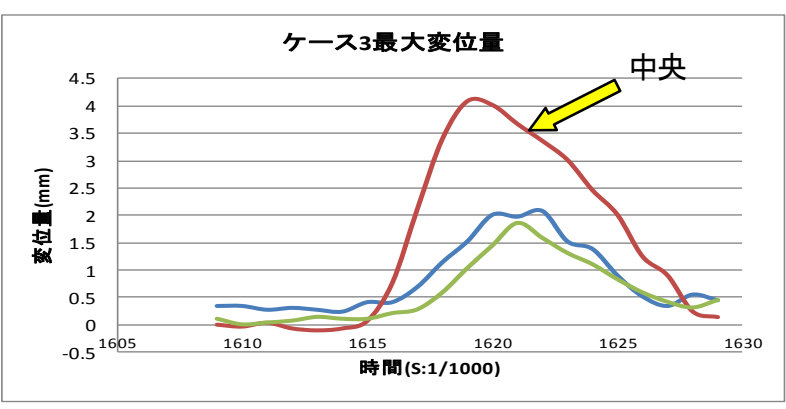

図-18 ケース3最大変位量

\section{5. 考察とまとめ}

これまでの結果により以下のことが確認できた.

(1)実物実験による変形を許容した設計の範囲と, 従来手 法である極限つり合い法による非変形の設計でほぼ整 合性が取れた。

(2)解析による変形状態と，モデル実験よるものがほぼ一 致した．また解析では表現できなかったがモデル実験 により変状形態に差はあってもいずれも破壊には至ら ないことが確認できた.

(3)解析で現れなかった最大変位と残留変位の差はジオグ リッドの敷設方向によるものと思われる.

(4)断面積を大きくすることで，抵抗力をあげることがで きるが，幅を大きくするより高さを高くする方が全体 的に安定する.

今回の研究では変形を許容することで，小さな形状で も大きな落石エネルギーを抑止することが可能であるこ とや，補強土壁の大きさと落石エネルギーのバランスに よる変形量も定量的に表現できる指標を示せた.

ただし変状が大きいと連続した落石へのリスクなど考 慮する必要があり，適用範囲やメンテナンス性も考慮し ながら効率のよい設計法を検討する.

\section{参考文献}

1)田島与典 : 実物大斜面落石実験によるジオグリッドとジオセ ルを用いた補強土壁の評価，ジオシンセティックス論文集 PP.221-226, 2010

2) 熊谷幸博 : 東日本大震災により被災した補強土を用いた落 石防護擁壁の被災事例，ジオシンセティックス論文集PP.7782, 2011

3) 小幡康隆 : ジオシンセティックスを用いた落石防護擁壁の 動的応答解析，ジオシンセティックス論文集PP.93-100，1999

4)井上昭一：日本における落石対策の現状と環境共生型落石防 護工法の開発，2010

5) 日本道路公団関西支社大阪技術事務所 : 落石防護補強土壁 工法設計の手引き (案) , 2002

6)日本道路協会「落石対策便覧」 


\section{ALLICABILITY EVALUATION OF ROCKFALL PROTECTION SOIL WALL BY MODEL TEST AND NUMERICAL ANALYSIS}

\section{Masaki YOSHIDA, Yukihiro KUMAGAI Sanae HASHIMOTO, Kosuke ROKUSA and Katsuhiko ARAI}

Rockfall protection soil wall, which it can absorb the rockfall energy from 100 to $3000 \mathrm{~kJ}$, has been widely applied to many rockfall protecting works. Conventionally, the wall is designed based on the limit equilibrium method, but the performance based design considering the deformation of the wall based on the experimental data is proposed in recent years. In order to rationalize the design method of the wall, authors carried out the model test and numerical analysis to confirm the behavior of the wall when the rock impacts the wall. Numerical analysis can simulate the behavior of the wall of the model test. This paper reports that it can extend the range of application of the rockfall protection soil wall for rockfall energy and field conditions.

KEYWORDS: Rockfall, Three-dimensional dynamic analysis, Reinforced soil wall, Model test 